UDC 338.23

DOI https://doi.org/10.32849/2663-5313/2021.10.07

\title{
Denys Koshykov,
}

Doctor of Law, Senior Lecturer at the Department of Police Activity and Public Administration, Kharkiv National University of Internal Affairs, 27, Lev Landau avenue, Kharkiv, Ukraine, postal code 61080, Denyskoshykov@ukr.net

ORCID: orcid.org/0000-0002-0985-2897

Koshykov, Denys (2021). Place of administrative law provisions in legal framework for implementing public policy on economic security of the state. Entrepreneurship, Economy and Law, 10, 43-49, doi https://doi.org/10.32849/2663-5313/2021.10.07

\section{PLACE OF ADMINISTRATIVE LAW PROVISIONS IN LEGAL FRAMEWORK FOR IMPLEMENTING PUBLIC POLICY ON ECONOMIC SECURITY OF THE STATE}

Abstract. The aim of the article is to clarify the place of administrative law provisions in the legal framework for implementing public policy on economic security of the State.

Results. The focus is on the complexity of the classification of legal provisions governing economic security in Ukraine due to the involvement of elements such as financial security, macroeconomic security, industrial security, energy security, foreign economic security, investment-innovation security. In this context, the body of legal regulations that form the framework for implementing public policy on economic security is analysed according to their legal force: the Constitution of Ukraine, international legal acts and treaties ratified by Ukraine in accordance with the established procedure, legal regulations (laws, codes) and by-laws (acts of the Government, central and local executive authorities). Certain shortcomings in the legal regulatory mechanism for making public policy on economic security of the State are underlined and ways of eliminating them are proposed.

Conclusions. It is proved that the specificity of the provisions of administrative law in the legal framework for implementing public policy on economic security is that they have clearly defined limits of their powers (scope of legal regulation), that is, the subject matter of the activities of the bodies of public administration and the public relations of an administrative nature that arise as a result of the exercise of managerial powers by them. Considering this, it is concluded that the provisions of the administrative legislation are aimed at regulating social relations of a managerial nature, arising between the State and economic entities or other legal and natural persons in the field of ensuring national economic security and its constituent branches. It is emphasized that the specificity of this relationship is that one of the parties is the State, represented by an authority, such as a public administration body vested with real powers, which has the right to require certain legal conduct from other participants.

Key words: economic security, national security, public policy, administrative and legal framework, actors, administrative legislation, optimization.

\section{Introduction}

Effective implementation of public policy on economic security requires the existence of a certain legal framework, which has several similar names "legal framework," "legal basis," "legal and regulatory framework" etc. However, literature review reveals no uniform definition of the content of these terms. Moreover, it can be argued that contemporary threats to Ukraine's national security and economic security, as part of that strategy, require careful analysis and improvement of legal provisions, regulating the relevant public relations and policies of the State in this field. Moreover, the focus should be on the importance of analysing the administrative and legal regulatory mechanism for implementing public policy on economic security, as that is, in our view, the key element: which ensures the implementation of power prescriptions in the daily activities of social actors in the field of economic security.

The complexity of the classification of legal provisions governing economic security in Ukraine is due to the involvement of elements such as financial security, macroeconomic security, industrial security, energy security, foreign economic security, investment-innovation security, etc. Therefore, we argue that the study 
of the legal framework for arranging the system of economic security and implementing public policy in this field should be carried out on the basis of the generally accepted classification of the content of legal regulations.

\section{The Constitution of Ukraine}

For example, the Basic Law stipulates that human rights and freedoms, and their guarantees determine the content and direction of the State's activities, that is, public policy in any field shall comply with the Constitution.

The State shall ensure protection of rights of all property rights holders and economic operators, and the social orientation of the economy. All the property rights holders shall be equal before the law (article 13). According to article 41, citizens may use the objects of State or communal property in order to satisfy their needs, no one shall be unlawfully deprived of the right to property, while the right to private property shall be inviolable. Article 42 provides for that everyone has the right to engage in business activities not prohibited by law, and the State protects competition in business activities. In the event of a violation of someone's rights, the Constitution guarantees everyone the right to appeal in court against the decisions, acts or omissions of State authorities or local self-government bodies, public officials. The Constitution also establishes the right of the Verkhovna Rada of Ukraine to approve State-wide programmes for economic, scientific, technical and social development, and also provides for the rule that exclusively the laws of Ukraine shall determine the legal framework for property, competition rules of antimonopoly regulation and principles of external relations and foreign economic activities (Article 92).

In turn, the Cabinet of Ministers is responsible for ensuring the economic independence of Ukraine and for implementing the State's domestic and foreign policy. This higher executive authority formulates and implements State-wide programmes for economic, scientific, technical, social and cultural development (Article 116) (Constitution of Ukraine, 1996).

\section{Legal regulations}

These are, first of all, the provisions of the codes of Ukraine and the laws of Ukraine. Among the first relevant documents are Tax Code of Ukraine 2755-VI as of 02 December 2010, Customs Code of Ukraine 4495-VI as of 13 March 2012, Budget Code of Ukraine 2456-VI as of 08 July 2010, Bankruptcy Procedure Code of Ukraine 2597-VIII as of 18 October 2018, Economic Code of Ukraine 436-IV as of 16 January 2003.

For example, the Economic Code establishes the basic principles of economic activity in Ukraine and regulates economic relations arising in the process of organizing and carrying out economic activities between economic entities, as well as between these entities and other participants in the economic field (Economic Code of Ukraine, 2003). The Budget Code regulates relations arising in the process of making, examining, approving, implementing budgets, reporting on and monitoring compliance with budgetary legislation, and issues of liability for violations of budgetary legislation, as well as defines the legal framework for generating and reimbursing the State and local debt (Budget Code of Ukraine, 2020). The Customs Code of Ukraine establishes the procedure and conditions for the movement of goods across the customs border of Ukraine, their customs control and customs clearance, State control, in accordance with the law, of non-food products when they enter the customs territory of Ukraine, preventing and counteracting smuggling, combating violations of customs rules, organizing and ensuring the activities of customs bodies (Customs Code of Ukraine, 2012).

Next, the focus should be on laws that define foreign and domestic policy of the State, including in the field of economic security: "On the fundamentals of public regional policy" 156-VIII as of 05 February 2015, "On the fundamentals of domestic and foreign policy" 2411VI as of 01 July 2010, "On the national security of Ukraine" 2469-VIII as of 21 June 2018 , "On the State regulation of the securities market in Ukraine" 448/96-VR as of 30 October 1996, "On protection from unfair competition" 236/96-VR as of 07 June 1996, "On investment activity” 1560-XII as of 18 September 1991.

The basic principles of domestic economic policy are: to ensure the competitiveness of the national economy, to achieve a high rate of its growth, to ensure macroeconomic stability and a low level of inflation; to maintain a stable, rational and fair tax policies; to improve protection of the rights of depositors; to ensure economic balance in the development of the regions, harmonizing the vectors of their development with the national needs; anti-shadowing of the economy, an enabling environment for the activity of economic agents in a lawful manner. In turn, the basic principles for foreign policy are the use of international potential for the establishment and development of Ukraine as a sovereign, independent, democratic, social and legal State and for its sustainable economic development; an enabling environment for foreign policy in order to develop the Ukrainian nation and its economic potential; support for the development of trade and economic, scientific and technical, and investment cooperation between Ukraine and foreign States on the basis 
of mutual benefit; ensuring the integration of the Ukrainian economy into the world economic system, with a view to achieving full economic development and enhancing the well-being of the people (Law of Ukraine On Principles of Domestic and Foreign Policy, 2010).

It is necessary to single out the provisions of laws establishing the legal status of some actors of economic security of the State, namely: "On the Cabinet of Ministers of Ukraine" 794VII as of 27 February 2014, "On the National Bank of Ukraine" 679-XIV as of 20 May 1999, "On the National Commission, implementing the state regulation in the field of energy and public services» from 22 September 2016VIII, "On the Antimonopoly Committee of Ukraine" 3659-XII as of 26 November 1993 , "On the Accounting Chamber" 576-VIII as of 02 July 2015. These laws provide for the rights and obligations of the relevant State bodies in the field of economic security, as well as their territorial and subject-matter competences.

4. By-laws

It should be noted that these provisions are provided for by Resolutions and Orders of the Cabinet of Ministers, departmental regulations of central executive authorities and local self-government. With regard to the regulations of the Government, the focus should be on instruments such as Resolution 571 "Some Issues of Public Investment Management" as of 22 July 2015, Resolution 83 "On the approval of the list of State property objects of strategic importance for the economy and State security" as of 04 March 2015, Resolution 838 "Issues of the Ministry of Economic Development, Trade and Agriculture" as of September 2019, Resolution 236 "On the State Fiscal Service of Ukraine" as of 21 May 2014, Order 569-r "On approval of the Concept of national security in the financial sector" as of 15 August 2012, Order 605-p "On the approval of the Energy Strategy of Ukraine up to 2035 'Safety, energy efficiency, competitiveness' as of 18 August 2017.

Therefore, the Cabinet of Ministers of Ukraine adopts national economic security programmes and plans aimed at their implementation. At the same time, the Government of Ukraine has the authority to approve provisions on central executive bodies responsible for making public policy on the State's national economic security.

The emphasis should be on the role of the President of Ukraine, who is the guarantor of the rights and freedoms of citizens and the guarantor of social stability and is responsible for national security, of which economic security is an integral part. The President of Ukraine, in exercise of the powers conferred on him by the Constitution of Ukraine, issues legal regulations aimed at making the basic provisions of economic security, such as, Decree 453/2019 Issues of the National Anti-Corruption Policy Council as of 25 June 2019, Decree 206/2020 "On the Energy Security Council" as of 29 May 2020

In the context of the subject matter of this study, the role of the Head of State in directing and implementing the decisions of the National Security and Defence Council of Ukraine is important. According to the Constitution of Ukraine, the National Security and Defence Council is the coordinating body for national security and defence under the President of Ukraine. The Chairman of the National Security and Defence Council of Ukraine is the President of Ukraine, who forms its personal staff. Among the NSDC's decisions, enforced by presidential decrees, the provisions constituting the legal framework for the making public policy on economic security are Decree $58 / 2018$ "On the decision of the National Security and Defence Council of Ukraine as of March 1, 2018 'On urgent measures to protect the national interests of the State in the field of aircraft construction"” as of March 06, 2018, "On the decision of the National Security and Defence Council of Ukraine as of May 14, 2020, Decree 184/2020 "On the application, cancellation and introduction of changes in personal special economic and other restrictive measures (sanctions)" as of 14 May 2020, Decree $874 / 2019$ "On the Decision of the National Security and Defence Council of Ukraine as of December 2, 2019 'On urgent measures to ensure energy security”" as of December 02, 2019, "On the Decision of the National Security and Defence Council of Ukraine as of December 18, 2016, Decree 560/2016 "On urgent measures to ensure national security of Ukraine in economic sector and protection of interests of depositors" as of 18 December 2016, as well as Order 270/2016-rp "On delegation of Ukraine to participate in negotiations with the International Bank for Reconstruction and Development on conclusion of the Contract on Indemnity (Guarantee on supply of safety gas of Ukraine) between Ukraine and International Bank for Reconstruction and Development" of 09 November 2016.

At the local level, regulations adopted by local public administrations are important in ensuring regional economic security.

Local public administrations are responsible, inter alia, for the social and economic development of the relevant territories, the budget, finance and accounting, the administration of property, privatization, promotion of entrepreneurship development and implementation of public regulatory policy and foreign economic 
activity. For its part, the local public administration: drafts social and economic development programmes and submits them to the relevant Council for approval, ensures their implementation and reports to the relevant Council on their implementation; report to the Council on the advisability of placing new enterprises and other objects in the respective territory, regardless of the form of ownership; submit proposals for the establishment of special (free) economic zones, changes in the status and territory of such zones, in agreement with the relevant local self-government bodies; prepares, approves and submits to the Council for its consideration a forecast of the relevant budget; prepares and submits to the Council for approval the draft of the relevant budget and ensures its implementation; reports to the relevant Council on its implementation (Law of Ukraine On local state administrations, 1999).

\section{International regulations}

These documents are of importance, as they provide a basis for the implementation of global economic security policies, and they serve as guidelines for the adoption of national regulations governing economic issues, issues of fighting economic crime and promoting international cooperation in financial customs, investment activities, etc. Therefore, the focus should be on the provisions of international legal regulations, ratified by Ukraine, which constitute the legal principles for implementing public policy on economic security: 1) Final Act of the Conference on Security and Cooperation in Europe as of 01 August 1975; 2) Criminal Convention Against Corruption (ETS 173) as of 27 January 1999; 3) Civil Convention Against Corruption as of 04 November 1999; 4) Council of Europe Convention on Laundering, Search, Seizure and Confiscation of the Proceeds from Crime as of 16 May 2005; 5) International Code of Conduct for Public Officials as of 23 July 1996; 6) UN Resolution on Crime prevention and criminal justice in the context of development: implementation and prospects for international cooperation" as of 07 September 1990; 7) European Convention on Certain International Aspects of Bankruptcy (ETS 136) as of 05 June 1990; 8) Convention on Laundering, Search, Seizure and Confiscation of the Proceeds from Crime of 08 November 1990; 9) International Covenant on Economic, Social and Cultural Rights; 10) Energy Charter Treaty and its Final Act. Protocol on Energy Efficiency and Related Environmental Aspects as of 17 December 1994;11) Resolution "International Economic Security" as of 17 December 1985, etc.

The administrative legal provisions are of special importance in the legal framework for implementing public policy on economic security, because, in fact, they are a catalyst for translating the conceptual provisions of legal regulations into everyday activities related to strengthening economic security of the country. Administrative and legal provisions constitute the administrative and legal regulatory framework for implementing public policy by authorized public administrators. Therefore, this phenomenon will be further considered in detail.

The administrative and legal regulatory mechanism is important in implementing public policy on economic security of the State. As we have noted above, the legal framework for implementing public policy on economic security of the State should be considered primarily as a system of law provisions, enshrined in current Ukrainian legislation and by-laws, programme and strategic documents of the State, which establish the objective, tasks, rules, order and procedures for the activities of authorized actors in ensuring economic security of the State.

In turn, administrative and legal provisions constitute the central element of the administrative and legal regulatory mechanism used by the authorized actors of public policy on economic security (public administration bodies) to regulate, steer and organise social economic relations. Therefore, in the mechanism for implementing public policy on economic security, with the help of the main instrument of the administrative and legal regulatory framework, that is, administrative and legal provisions, the authoritative instructions of laws, and codes, the Basic Law, international treaties and other institutional instruments are implemented into the practice of the State, its bodies and officials.

The key makers of legal and administrative provisions are the executive authorities: the Cabinet of Ministers of Ukraine, the central executive authorities and local executive authorities.

The Cabinet of Ministers of Ukraine, on the basis of and in compliance with the Constitution and laws of Ukraine, issues binding regulations, such as resolutions and orders. Regulations of the Cabinet of Ministers of Ukraine are issued in the form of Resolutions of the Cabinet of Ministers. Acts of the Cabinet of Ministers of Ukraine on organizational and administrative issues and other current issues are issued in the form of Orders of the Cabinet of Ministers of Ukraine (Law of Ukraine On the Cabinet of Ministers of Ukraine, 2014).

The Ministry, within the scope of its powers, issues orders signed by the Minister. The central executive authority, within the scope of its powers, on the basis of and in compliance 
with the Constitution and laws of Ukraine, issues managerial orders, organizes and controls their implementation (Law of Ukraine On Central Bodies of Executive Power, 2011), in turn, the head of the local State administration, within the scope of his/her powers, issues directives, while the heads of structural units issue orders (Law of Ukraine On local state administrations, 1999)

The administrative and legal regulations on public economic policy and policy on national and regional economic security are as follows: Instructions on the processing of materials relating to administrative offences by bodies of revenue and duties, and Procedure for obtaining information on taxpayers' accounts registered with the control authorities by the National Agency of Ukraine for finding, tracing and management of assets derived from corruption and other crimes, Advisory clarifications on the application of the provisions of Parts 2, 5 and 6 of Article 52 of the Law of Ukraine "On protection of economic competition," Parts 1 and 2 of Article 21 of the Law of Ukraine "On protection against unfair competition," the Form of the regulation on the basis of the results of planned (unplanned) event of State supervision (control) of compliance with the requirements of the law on consumer protection by the economic entity, Regulations on financial monitoring by primary financial monitoring entities, Regulations on the application of sanctions to non-banking financial institutions.

The focus should be on administrative and legal regulations, adopted by local executive authorities, such as the Order of the Head of the Kharkiv Regional State Administration "On expansion of production of a type of economic activity," "On approval of the plan of measures for 2020 on filling local budgets of the region, economical and rational use of budget funds in the process of implementation of local budgets"; the Order of the Head of the Dnipropetrovsk Regional State Administration "On approval of the 2020 Procedure for granting and use of the subvention from the regional budget to local budgets for social and economic development," "On approval of the Regulation on the procedure of initiation and submission of investment projects of AllUkrainian Public Budget of Dnipropetrovsk Oblast."

In addition to the adoption of administrative provisions, the administrative and legal regulatory mechanism for implementing public policy on economic security is reflected in the exercise of managerial powers, such as control, inspection, organizational powers of administrative and legal nature, by authorized public administrators.

\section{Conclusions}

However, along with this analysis of the legal framework for implementing public policy on economic security, certain shortcomings in the legal regulatory mechanism for making public policy on economic security of the State should be underlined:

1. First of all, our country lacks a strategic (conceptual) instrument on economic security. This issue is very important in the context of the global economic crisis and the increase in government borrowing. The formulation and adoption of the National Economic Security Strategy should be the main reference point for the State's efforts to promote both own economic interests and economic security of everyone, who lives in our country.

2. The next step, in our opinion, should be the introduction of appropriate amendments to the Law of Ukraine "On National Security" with regard to singling out its part on the issues of economic security. The grounds for this proposal are the fact that the security and defence sector is based on the economic indicators of the development of the State, that is, a strong economy can defend the country according to the best international standards.

3. The issue of legislative support for the operation of an independent financial investigation body, which has already been announced on several occasions by the State authorities, is a topical one.

4. Ukraine's legislation governing the Accounting Chamber of Ukraine requires improving for better State control over the use of budgetary funds.

These issues will be discussed in detail in our further study.

The analysis of the legal framework for implementing public policy on State economic security enables to make certain conclusions and overviews.

1. The legal framework for implementing public policy on economic security of the State should be considered primarily as a system of law provisions, enshrined in current Ukrainian legislation and by-laws, programme and strategic documents of the State, which establish the objective, tasks, rules, order and procedures for the activities of authorized actors related to regulating and developing public economic relations, ensuring citizens' social and economic rights and freedoms and protecting them in the event of violations; an enabling environment for the further development and growth of the national economy and ensuring competitiveness (Koshykov, 2020).

2. The legal framework for implementing public policy on economic security in Ukraine is contained in the Constitution, legislative 
acts (laws, codes) and by-laws (regulations of the Government, central and local executive authorities), international legal acts and agreements ratified by Ukraine in accordance with the established procedure.

3. The administrative legal provisions are of special importance in the legal framework for implementing public policy on economic security, because they constitute the administrative and legal regulatory framework for implementing public policy by authorized public administrators. (Koshykov, 2020). These provisions are mainly contained in by-laws adopted by the Government of Ukraine, ministries and central and local executive authorities. In addition to the adoption of administrative provisions, the administrative and legal regulatory mechanism for implementing public policy on economic security is reflected in the exercise of managerial powers, such as control, inspection, organizational powers of administrative and legal nature, by authorized public administrators.
4. The specificity of the provisions of administrative law in the legal framework for implementing public policy on economic security is that they have clearly defined limits of their powers (scope of legal regulation), that is, the subject matter of the activities of the bodies of public administration and the public relations of an administrative nature that arise as a result of the exercise of managerial powers by them. This statement enables to argue that the object of administrative and legal regulatory mechanism for the implementation of public policy on economic security of the State is public relations of a managerial nature, arising between the State and economic entities or other legal and natural persons in the field of ensuring national economic security and its constituent branches. The specificity of this relationship is that one of the parties is the State, represented by an authority, such as a public administration body vested with real powers, which has the right to require certain legal conduct from other participants.

\section{References:}

Biudzhetnyi kodeks Ukrainy: pryiniatyi 8 lyp. 2010 № 2456-VI [Budget Code of Ukraine from July 82020 № 2456-VI]. (2020). rada.gov.ua. Retrieved from https://zakon.rada.gov.ua/laws/ show/2456-17 (in Ukrainian).

Hospodarskyi kodeks Ukrainy: pryiniatyi 16 sich. 2003 № 436-IV [Economic Code of Ukraine from January 162003 № 436-IV]. (2003). rada.gov.ua. Retrieved from https://zakon.rada.gov.ua/ laws/show/436-15 (in Ukrainian).

Konstytutsiia Ukrainy: pryiniata 28 cherv. 1996 roku [Constitution of Ukraine from June 28 1996]. (2018, April 11). Kyiv: vyd-vo PALYVODA (in Ukrainian).

Koshykov, D.O. (2020). Administratyvno-pravovi zasady realizatsii derzhavnoi polityky u sferi zabezpechennia ekonomichnoi bezpeky derzhavy [Administrative and legal frameworkof realization of the public policy on maintenance of economic safety of the state]. Kharkiv: Panov (in Ukrainian).

Mytnyi kodeks Ukrainy: pryiniatyi 13 berez. 2012 № 4495-VI [Customs Code of Ukraine from March 132012 № 4495-VI]. (2012). rada.gov.ua. Retrieved from https://zakon.rada.gov.ua/laws/ show/4495-17 (in Ukrainian).

Zakon Ukrainy Pro Kabinet Ministriv Ukrainy: pryiniatyi 27 liut. 2014 roku № 794-VII [Law of Ukraine On the Cabinet of Ministers of Ukraine from February 27 2014 № 794-VII]. (2014). rada. gov.ua. Retrieved from https://zakon.rada.gov.ua/laws/show/794-18 (in Ukrainian).

Zakon Ukrainy Pro mistsevi derzhavni administratsii: pryiniatyi 9 kvit. 1999 roku № 586-XIV [Law of Ukraine On local state administrations from April 91999 № 586-XIV]. (1999). rada.goz.ua. Retrieved from https://zakon.rada.gov.ua/laws/show/586-14\#Text (in Ukrainian).

Zakon Ukrainy Pro tsentralni orhany vykonavchoi vlady: pryiniatyi 17 berez. 2014 roku № 3166-VI [Law of Ukraine On Central Bodies of Executive Power from March 172011 № 3166VI] (in Ukrainian).

Zakon Ukrainy Pro zasady vnutrishnoi i zovnishnoi polityky: pryiniatyi 1 lyp. 2010 № 2411VI [Law of Ukraine On Principles of Domestic and Foreign Policy July 12010 № 2411-VI]. (2010). rada.goz.ua. Retrieved from https://zakon.rada.gov.ua/laws/show/2411-17(in Ukrainian).

\section{Денис Кошиков,}

доктор юридичних наук, старший викладач кафедри полічейської діяльності та публічного адміністрування, Харківський національний університет внутрішніх справ, проспект Льва Ландау, 27, Харків, Україна, індекс61080,Denyskoshykov@ukr.net

ORCID: 0000-0002-0985-2897 


\section{МІСЦЕ ПОЛОЖЕНЬ АДМІНІСТРАТИВНОГО ЗАКОНОДАВСТВА В СИСТЕМІ ПРАВОВИХ ЗАСАД РЕАЛІЗАЦІЇ ДЕРЖАВНОЇ ПОЛІТИКИ У СФЕРІ ЗАБЕЗПЕЧЕННЯ ЕКОНОМІЧНОЇ БЕЗПЕКИ ДЕРЖАВИ}

Анотація. Метою статmi є з'ясування місця положень адміністративного законодавства в системі правових засад реалізації державної політики у сфері забезпечення економічної безпеки держави.

Результати. Наголошено на тому, що складність класифікації правових норм, які регулюють питання забезпечення економічної безпеки України, зумовлюється тим, що до їі складових елементів належать фінансова безпека, макроекономічна безпека, виробнича безпека, енергетична безпека, зовнішньоекономічна безпека, інвестиційно-інноваційна безпека тощо. У зв'язку із цим проаналізовано сукупність нормативно-правових актів, які становлять основу правових засад реалізації державної політики у сфері економічної безпеки, за юридичною силою, зокрема: Конституцію України, міжнародні нормативно-правові акти та угоди, ратифіковані Україною у встановленому порядку, законодавчі акти (закони, кодекси), підзаконні нормативні акти (акти уряду, центральних і місцевих органів виконавчої влади). Акцентовано на певних недоліках у правовому регулюванні формування й реалізації державної політики у сфері забезпечення економічної безпеки держави та запропоновано шляхи їх усунення.

Висновки. Доведено, що особливістю норм адміністративного законодавства в системі правових засад реалізації державної політики у сфері економічної безпеки є те, що вони мають чітко визначену межу своєї дії (межі правового регулювання), а саме предметну сферу діяльності органів публічної адміністрації та суспільні відносини управлінського характеру, що складаються внаслідок реалізації ними організаційно-владних повноважень. 3 огляду на це зроблено висновок, що норми адміністративного законодавства спрямовані на впорядкування суспільних відносин управлінського характеру, які виникають між державою та суб'єктами господарювання або іншими юридичними та фізичними особами у сфері забезпечення національної економічної безпеки і ії складників. Підкреслено, що особливістю цих відносин є те, що однією зі сторін є держава в особі суб'єкта владних повноважень - органу публічної адміністрації, наділеного владними повноваженнями, який має право вимагати від інших учасників певної правової поведінки.

Ключові слова: економічна безпека, національна безпека, державна політика, адміністративноправові засади, суб'єкти, адміністративне законодавство, оптимізація.

The article was submitted 15.10.2021

The article was revised 05.11.2021

The article was accepted 26.11.2021 